\title{
SELF-FERTILITY IN TRIFOLIUM FRAGIFERUM
}

\author{
W. ELLIS DAVIES and NORMAN R. YOUNG \\ Welsh Plant Breeding Station, Aberystwyth
}

Received 28.ii.66

\section{INTRODUCTION}

STRAWBERRY clover has been frequently reported to be a perennial species which is self-fertile, which makes it an exception to the general rule that most perennials are self-sterile and, conversely, most annuals self-fertile (Stebbins, 1950). Only Williams (193I) who tested 8 plants of New Zealand origin, and Trimble (1950) who artificially selfpollinated ro plants, give data on which they have based this statement. Johnson (195I), Williams (195I) and Fryxell (1957) appear to merely quote that conclusion.

More recently, Morley (1963), using I I introductions from Europe and the Middle East, as well as two Australian varieties, concluded that strawberry clover is predominantly self-incompatible, although a small proportion of plants set a few seeds on selfing. Wright (1964) also used two Australian varieties and 3 from each of the 18 indigenous New Zealand populations; although he came to the same conclusion, i i out of 63 clones set an average of 46 per cent. of seed autogamously. Evans (1962 and personal communication) followed Trimble's (1951) procedures and obtained a mean self-fertility of 84 per cent. for plants grown from seed collected in a Polish meadow.

The present investigation was initiated because strawberry clover has some potential as a clover for wet grassland, as well as interesting fertility relationships. The work of Morley (1963) and Wright (1964) had not been published at that time.

\section{MATERIALS AND METHODS}

The sources of material used are detailed in table $\mathrm{r}$. Plants were grown in a beeproofed glasshouse and 40-10o florets were manipulated with a folded triangular piece of card to simulate the action of pollinating bees. This tripping increased both the number of plants setting seed (from 14 to $2 \mathrm{I}$ plants) and the percentage of seed set (from 42.3 to 62.3 per cent.) when compared with spontaneous seed set in the same clones. Plants were classified self-fertile if they set ro per cent. or more, seed.

The high level of self-fertility found in some plants allowed exploration of the effects of continued seling and, where possible, the scheme on p. $6 \mathrm{r} 7$ was adopted.

Ten plants from each progeny were tested for self-fertility and two of these were selected to continue inbreeding, except in $\mathrm{S}_{3}$ where only one of each was continued. These selections were based more on high seed number than on high percentage seed set.

Seed setting was determined in succeeding years so that this result was confounded with environmental conditions during seed development. The resulting seed was then placed in cold storage $\left(0^{\circ} \mathrm{C}\right.$.) until all the inbreeding lines were produced. Experience has shown that white clover would remain virtually unchanged 


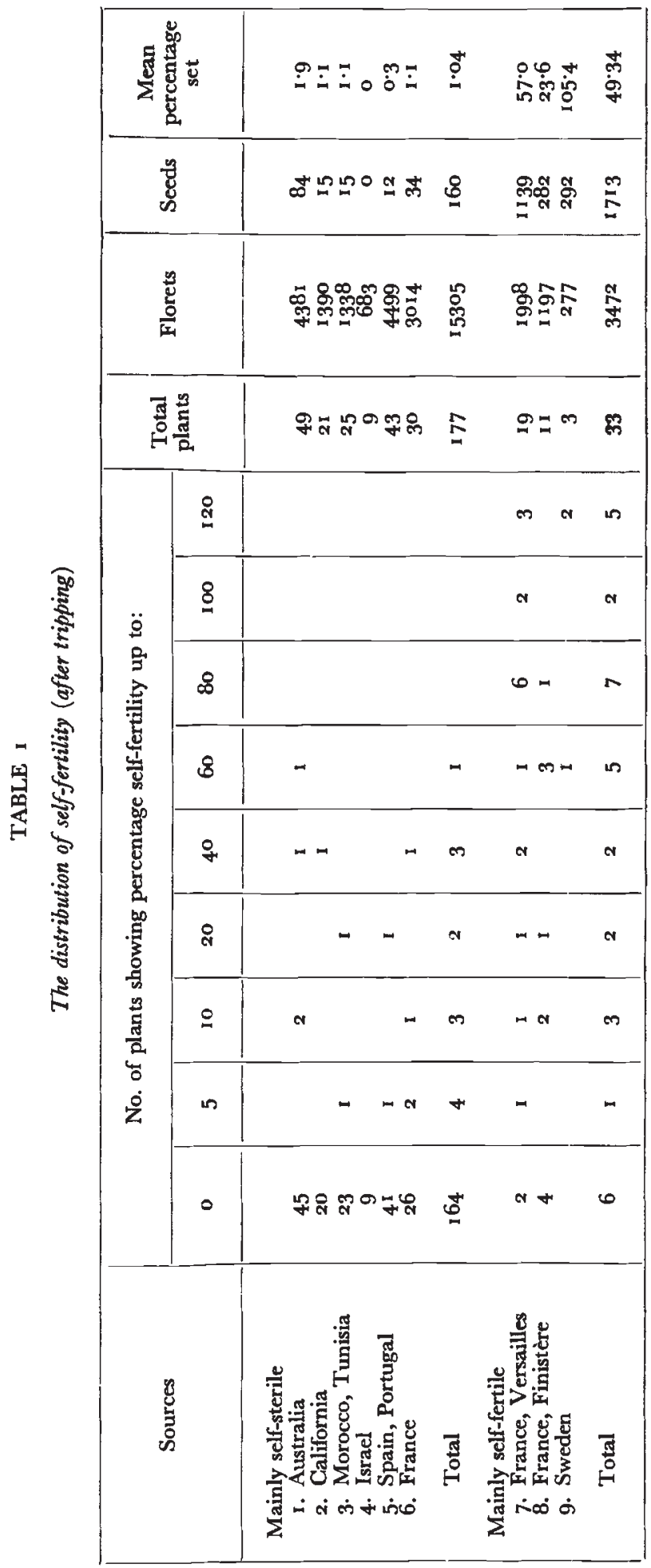

兘

:

를

80

$8 \cdot 5$

สิ

ن

. ํㅗㄹ

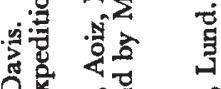

a

نَّْ

สึ สำ

कृष

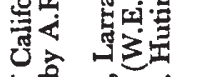

ชี สึ

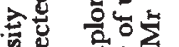

氙

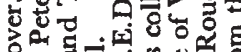

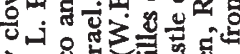

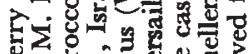

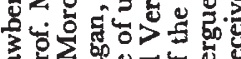

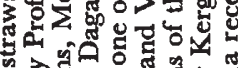
के -

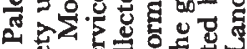

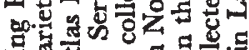

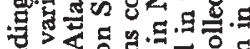

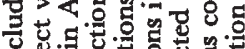

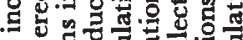
ช.

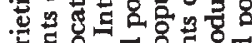

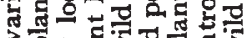

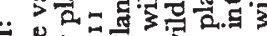

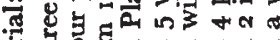

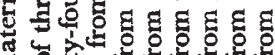

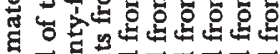
论

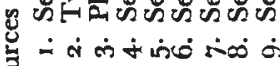


$S_{0} \quad$ Self-fertile parent plant

$S_{1}$

$\mathrm{S}_{2}$

$\mathrm{S}_{3}$

$\mathrm{S}_{4}$
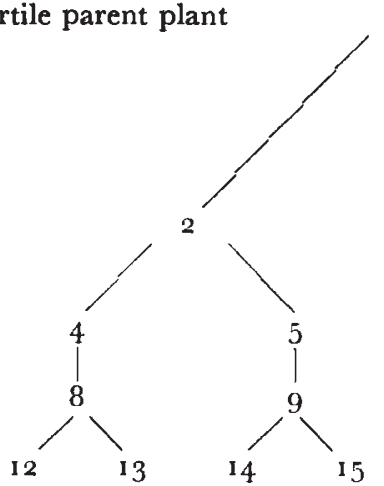

I

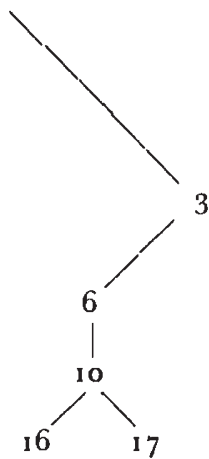

3

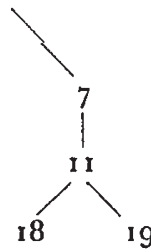

over this period of years (Davies, 1965 ). The seed weights of the original seed and $S_{1}$ seed of lines $B$ and $C$ were about 20 per cent. less than the remainder, but otherwise there were no significant trends between lines or generations.

Three lines (A, B, and C) with complete sets of 18 progenies and one with only 6 progenies (line $\mathrm{X}$ ) were produced. Where possible, 40 seeds per half box were sown in 4 replicates on 3 August and reduced to 25 at random. Data were collected on speed of germination, rate of leaf appearance, leaf size, tillering, green weight and dry weight of 4490 seedlings.

\section{RESULTS \\ (i) Self-fertility}

Data from the preliminary screening for self-fertility are summarised in table $\mathrm{I}$. Populations which originated in areas with a Mediterranean climate (this includes the Australian material) are almost completely self-sterile. Two of the three groups from France and also the Swedish sample, are distributed in classes up to $\mathrm{I} 20$ per cent. seed set with a mean of 49.3 per cent. compared with $\mathrm{I} \cdot \mathrm{O}$ per cent. for the mainly selfsterile populations.

Of the four lines which produced enough seed to initiate the subsequent stage, three (i.e. A, B, and $\mathrm{G}$ ) were from the largely self-fertile Versailles group. No difficulty was experienced in maintaining these as selfed lines, and each increased in self-fertility (table 2). The fourth line (i.e. X) was produced from a self-fertile plant in an otherwise

TABLE 2

The mean percentage self-fertility of four inbred lines

\begin{tabular}{|c|c|c|c|c|}
\hline \multirow{2}{*}{ Generation } & \multicolumn{4}{|c|}{ Lines } \\
\hline & A & B & C & $\mathrm{X}$ \\
\hline $\begin{array}{l}S_{0} \\
S_{1} \\
S_{2} \\
S_{3}\end{array}$ & $\begin{array}{r}36 \\
93 \\
116 \\
125\end{array}$ & $\begin{array}{r}56 \\
106 \\
113 \\
128\end{array}$ & $\begin{array}{r}82 \\
102 \\
102 \\
142\end{array}$ & $\begin{array}{r}4 \\
9 \\
53 \\
2\end{array}$ \\
\hline
\end{tabular}

$2 \mathrm{R}$ 
self-sterile Australian population. The range of variation in the selffertility of individual plants of lines B and $\mathrm{X}$ is shown in fig. I. The

Generation

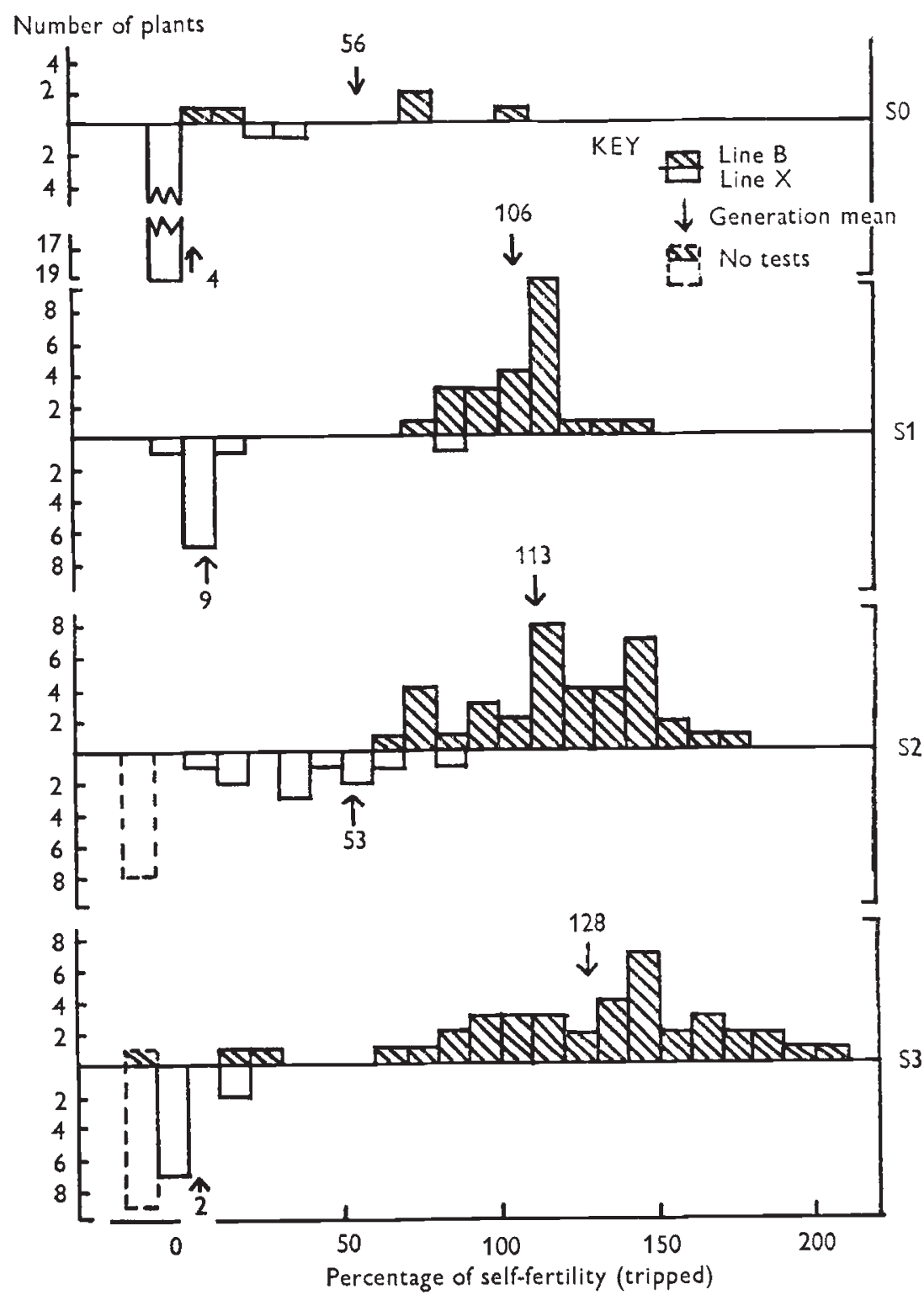

FIG. I.-Distribution of self-fertility in two selfed lines. Line B is self fertile but line X originated from a self-fertile plant in an otherwise self-sterile line. (Mean shown by arrow $\downarrow$; no tests due to non-flowering plants.)

self-fertility of line $B$ continued to improve to $S_{3}$ mainly due to an increase in the upper range of self-fertility. Line $\mathrm{X}$ on the other hand also increased as far as $S_{2}$, but even at this stage eight out of ig plants 
could not be tested as they were too weak or did not flower. In $\mathrm{S}_{3}$ the situation deteriorated and only two plants produced any seed. Line $\mathrm{X}$ would, therefore, appear to suffer more inbreeding depression than line $\mathrm{B}$.

Two factors may affect these data. Firstly, in this kind of experiment selection for increased self-fertility is unavoidable; nearly all the parents used had a self-fertility above the mean of the line. Secondly, self-fertility is affected by environmental conditions; the annual variations may be of considerable magnitude as indicated by the following percentage seed set from the same seven plants in different years:

$\begin{array}{lcc} & 1957 & 1960 \\ \text { Mean } & 68 \cdot 6 & 122 \cdot 7 \\ \text { Range } & 4^{2-108} & 95-146\end{array}$

The difference in seed setting is of the same order as the increase from $\mathrm{S}_{0}$ to $\mathrm{S}_{3}$, and suggests that the latter trend needs to be interpreted with caution.

\section{(ii) Germination}

The progress of germination was studied in detail but there was no discernible trend in successive generations nor any marked difference between lines in the self-fertile group; all their generation means increased linearly from the $3^{\text {rd }}$ to the 8 th day reaching $5^{8-88}$ per cent. of maximum in this time, and falling off after this with highest counts on the 18 th day. Line $\mathrm{X}$ showed a similar pattern with no generation differences but taking more than 8 days to reach 5 o per cent. of maximum and the linear increase continuing to the IIth day.

The rate of appearance of the third trifoliate leaf also followed this pattern; the earliest to germinate were the first to produce leaves. Line $\mathrm{X}$ again lagged behind.

Mean germination data indicate a downward trend at the $\mathrm{S}_{4}$ level and figures within this generation reveal much greater variation between progenies than in previous generations (Fig. 2). Line $\mathrm{X}$ gave generally lower results than the others.

\section{(iii) Growth of seedlings}

The subsequent growth of seedlings was studied and data were collected at various intervals on the number of leaves, petiole length, leaflet length, tiller number and finally, dry weight of the plants harvested 75 days after sowing. An analysis of variance revealed no significant differences among the self-fertile lines and no significant lines $\times$ generations interaction. Data for the three lines are therefore pooled in table 3. Differences between generations are small and mostly non-significant. 


\section{Germination per cent}

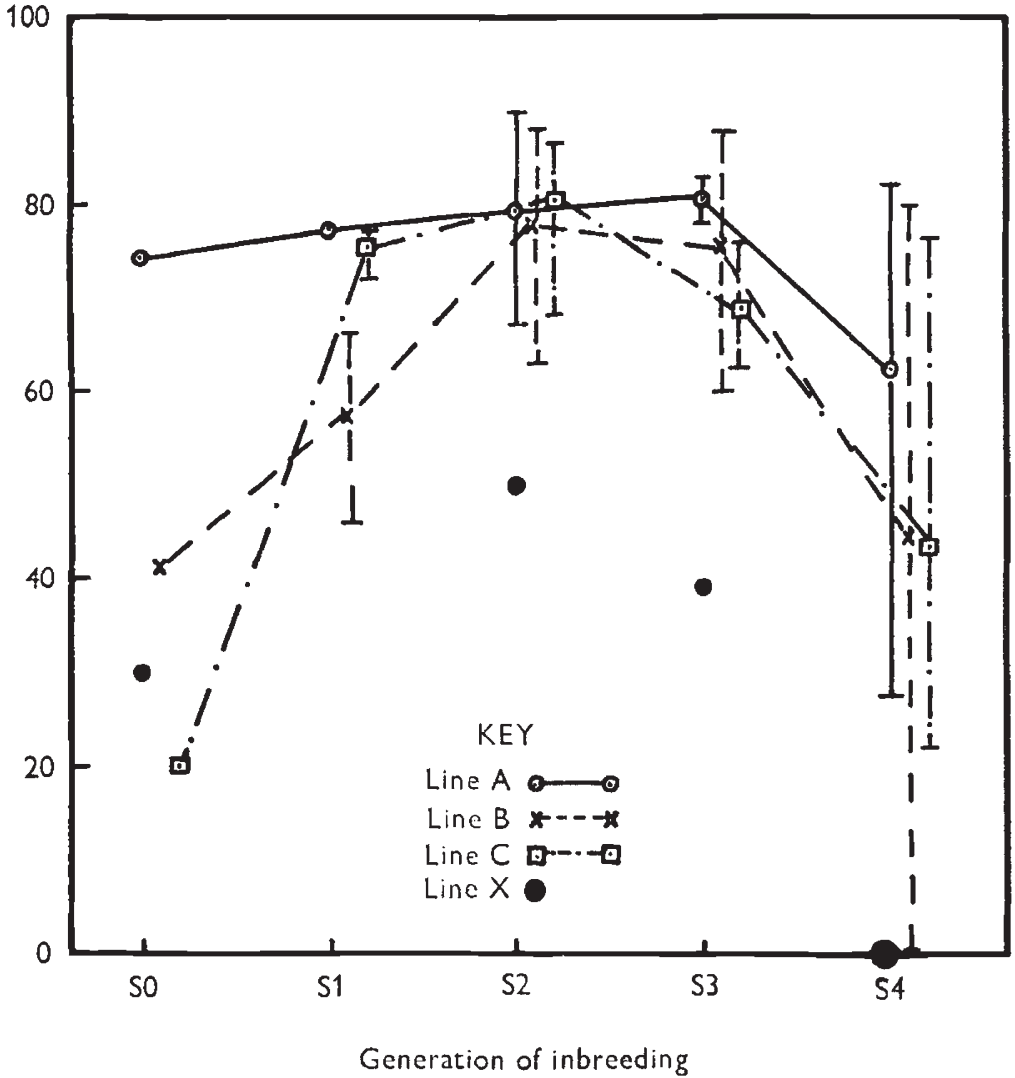

Fig. 2.-Germination of inbred lines. (Vertical lines indicate range of family means.)

TABLE 3

Growth of seedlings inbred to fourth generation

\begin{tabular}{|c|c|c|c|c|}
\hline & $\begin{array}{l}\text { Number of } \\
\text { trifoliate } \\
\text { leaves }\end{array}$ & $\begin{array}{l}\text { Length }(\mathrm{mm} .) \text { of } \\
\text { central leaflet of } \\
\text { 3rd trifoliate leaf }\end{array}$ & $\begin{array}{l}\text { Number of } \\
\text { tillers }\end{array}$ & $\begin{array}{l}\text { Dry weight/ } \\
\text { plant }(\mathbf{g} .)\end{array}$ \\
\hline Days from sowing & 35 & $47-50$ & $6 r-67$ & $75-78$ \\
\hline $\begin{array}{c}\text { Lines A, B, and C } \\
S_{\mathrm{S}_{0}} \\
\mathrm{~S}_{1} \\
\mathrm{~S}_{2} \\
\mathrm{~S}_{3} \\
\mathrm{~S}_{4} \\
\text { S.E. }( \pm)\end{array}$ & $\begin{array}{l}2 \cdot 7 \\
2 \cdot 7 \\
2 \cdot 9 \\
2 \cdot 8 \\
3 \cdot 0 \\
0 \cdot 108\end{array}$ & 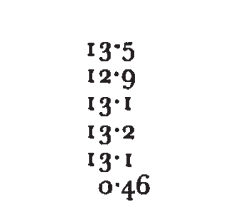 & $\begin{array}{l}4 \cdot 1 \\
3 \cdot 9 \\
3 \cdot 9 \\
4 \cdot 1 \\
4 \cdot 2 \\
0 \cdot 166\end{array}$ & $\begin{array}{l}0 \cdot 31 \\
0 \cdot 31 \\
0 \cdot 26 \\
0 \cdot 29 \\
0 \cdot 3^{I} \\
0 \cdot 03^{2}\end{array}$ \\
\hline $\begin{array}{r}\text { Line } \\
\mathrm{S}_{\mathbf{0}} \\
\mathrm{S}_{2} \\
\mathrm{~S}_{\mathbf{3}}\end{array}$ & $\begin{array}{l}\mathrm{I} \cdot 8 \\
\mathrm{I} \cdot 6 \\
\mathrm{I} \cdot 7\end{array}$ & $\begin{array}{l}8 \cdot 3 \\
7 \cdot 8 \\
8 \cdot 6\end{array}$ & $\begin{array}{l}2 \cdot 4 \\
3 \cdot 9 \\
3 \cdot 5\end{array}$ & $\begin{array}{l}0 \cdot 16 \\
0 \cdot 12 \\
0 \cdot 18\end{array}$ \\
\hline
\end{tabular}


Variation between progenies within lines sometimes showed significant differences but in general the progenies tended to regress toward the mean of the line as a whole.

The limited data on line $\mathrm{X}$ which was established from a largely self-sterile population, did not appear to show inbreeding depression for the seedling characters observed (table 3 ). These values were much lower than those for the three self-fertile lines from northern France, but this is attributable to a differing inherent growth pattern; the French material adapted to summer growth became almost dormant in winter, while the Mediterranean type was still actively growing (table 4).

TABLE 4

Winter growth of Mediterranean type population and north-European population

\begin{tabular}{|l|c|c|}
\hline & $\begin{array}{c}\text { Mediterranean } \\
\text { Line X }\end{array}$ & $\begin{array}{c}\text { N. European } \\
\text { Line B }\end{array}$ \\
\hline Number of tillers & $4 \cdot 9$ & $8 \cdot 0$ \\
Height of plant (mm.) & $16 \mathrm{I} \cdot 6$ & $82 \cdot 1$ \\
Length of leaf (mm.) & $22 \cdot 4$ & $1 \mathrm{~m} \cdot 4$ \\
Breadth of leaf (mm.) & $14 \cdot 9$ & $6 \cdot 6$ \\
Dry weight/plant (g.) & $10 \cdot 3$ & $6 \cdot 3$ \\
\hline
\end{tabular}

\section{DISCUSSION}

Stebbins (1950) concluded that cross fertilisation is the ancestral breeding system among plants, largely because it promotes greater evolutionary flexibility. Self-fertilising species have repeatedly evolved in various taxa presumably in response to selection pressure for immediate fitness.

The present study suggests that such a trend has occurred in T. fragiferum during its spread into North-West Europe from the most probable centre of origin, the Mediterranean. Indigenous Mediterranean populations together with some recently derived from that region proved to be almost completely self-sterile. Other samples from $\mathrm{N}$. France and Sweden, however, showed a considerable degree of selffertility.

Morley (1963) observed that in an area where bees were plentiful they were visiting one group of strawberry clover plants, yet neglecting progeny plants some distance away; this suggests that the species does not have a very strong attraction for bees. In its spread northward from the centre of diversity, pollinators may have become more difficult to secure and there is evidence from other herbage legumes (e.g. red clover and lucerne) that pollination is much less effective in the colder, damper climate of the north temperate zone than in warmer climates. In the extreme case of introducing a species into a new environment, the 
absence of effective pollinating insects has caused normally crossfertilising plants to fertilise themselves e.g. tomatoes cross freely in their native tropics, but are compelled to self-fertilise in Europe (Darlington, I963).

Before this change can take place the mechanism of self-incompatibility must first be broken down. The type of incompatibility has not yet been worked out for $T$. fragiferum, but the Nicotiana gametophytic oppositional system has been shown to operate in $T$. repens, $T$. pratense and $T$. hybridum. While a degree of pseudo-compatibility, and even an occasional self-fertile allele occurs (Williams, I95I) none of these species have reached the degree of self-fertility found in strawberry clover.

The chief barrier to subsequent development of self-fertilising lines from a cross-fertilising species is that the population faces serious inbreeding depression resulting from large numbers of deleterious recessives being brought from a heterozygous to a homozygous condition.

In $T$. pratense, a diploid species with an efficient self-incompatibility system, Williams (I 937a) found that inbred $\mathrm{F}_{2}$ families produced 6065 per cent. and $F_{3}$ families $40-45$ per cent. of the corresponding $F_{1}$ yield, and over 50 per cent. of plants in some varieties were heterozygous for chlorophyll deficiency. Many of these types, when homozygous, were either lethal in the seedling stage or were weaker than the normal plants (Williams, $1937 b$ ). This barrier can be surmounted if the genetic system passes through a stage of facultative and increasing self-fertilisation. When the species is perennial, the long life and excess of reproductive potential of the successful genotypes may permit the population to tolerate the numerous inviable or deleterious gene combinations and so remove them gradually (Stebbins, I950, 1958).

This process appears already to have taken place in the self-fertile lines of $T$. fragiferum studied here, as they showed no loss of vigour on selfing. Even the largely self-incompatible line, on which data were limited, showed no depression of growth up to $S_{3}$, although self-fertility was seriously impaired. The frequency of deleterious recessives as indicated by abnormalities was also low in the selfed progenies.

In the initial screening of populations some plants increased in seed setting when manipulated, and seven plants (including all 4 of one Finistère sample) set seed only when tripped. These plants appear to represent different levels in the stage of facultative self-fertilisation.

The results of Morley ( 1963 ) agree with the present findings when source of origin is considered. The higher self-fertility which Wright (1964) found in the New Zealand material, and the high degree of selffertility in Evans' (1965) Polish sample parallels that found in the Versailles, Finistère and Swedish populations. Wright was unable to show differences within indigenous lines or between these and the two Australian varieties, possibly because the samples were too small. $\mathrm{He}$ also indicated that his autogamous lines had a general lack of vigour 
and produced a smaller number of florets, suggesting that this was a result of past inbreeding. The self-fertile $\mathrm{S}_{0}$ plants in this study did not produce fewer florets per head than the self-sterile plants. It is, however, difficult to estimate the level of homozygosity in such material, and even in autogamous lines there is always a proportion of outcrossing (Stebbins, 1958). The level of inbreeding in the present $S_{0}$ populations is also unknown, but it is significant that further selfing to $S_{4}$ did not reveal depression in the characters studied, though in the fourth generation poor germination indicated some disturbance. The significance of this requires further investigation.

Finally, direct comparison between self-sterile and self-fertile indigenous populations was complicated by the fact that they were also adapted to different climates, and therefore some of the observed differences may be a consequence of this. Field data were also collected from spaced plants of French origin, which were subsequently classified for self-fertility; the following figures average recordings made on 3 different dates for relative growth on an arbitrary scale $(\mathrm{I}=$ best, $9=$ poorest $)$ :

Mean growth marks for populations largely:

$$
\begin{array}{cc}
\text { self-fertile } & \text { self-sterile } \\
6 \cdot 4,6 \cdot 6,6 \cdot 6 & 5 \cdot 4,5 \cdot 5,6 \cdot 1,6 \cdot 5
\end{array}
$$

S.E. $\pm 0 \cdot 30$

This shows that while the self-fertile populations were less vigorous on the whole, this is not invariably so and there are possibly other reasons for the observed vigour.

\section{SUMMARY}

(I) Trifolium fragiferum in its region of origin, the Mediterranean, is a self-sterile species, but with occasional self-fertile plants. These could not be maintained by inbreeding beyond $\mathrm{S}_{3}$ although vigour of growth did not show a marked depression.

(2) Although a perennial species, in which we expect self-sterility to be favoured in the long term, lines with various degrees of self-fertility have become established in its northern distribution. These show no inbreeding depression and could be maintained to $\mathrm{S}_{4}$ without any difficulty.

(3) This change is considered to have been brought about by the lack of insect pollinators.

\section{REFERENCES}

DARLINGTON, C. D. 1963. Chromosome botany and the origins of cultivated plants. G. Allen and Unwin. p. 163 .

DAviES, W. ElLIs. 1965. Storage of clover seed. II. Second interim report, 19551964. 7. Br. Grassld Soc., 11, 224-229.

EVANs, A. M. 1962. Species hybridisation in the genus Trifolium. 1. Methods of overcoming the barriers to species incompatibility. Euphytica, $I I, 164-176$. 
FRYXELL, P. A. 1957. Mode of reproduction of higher plants. Bot. Rev., 23, 135-233. Johnson, I. J. 195I. Table 9 in Forages: ed. by H. D. Hughes, M. E. Heath and D. S. Metcalf. Iowa State College Press, Iowa.

MORLEY, F. H. W. I963. The mode of pollination in strawberry clover (Trifolium fragiferum). Austr. 7. expt. Agric., Animal Husbn., 3, 5-8.

stebBins, G. L. 1950. Variation and evolution in plants. Columbia Univ. Press. 643 pp. STEBBINS, G. L. 1958. Longevity, habitat and release of genetic variability in the higher plants. Cold Spring Harb. Symp. Quant. Biol., 23, 365-378.

TRIMBLE, J. P. 1951. Interspecific hybridisation studies in the genus Trifolium $L$. M.Sc. thesis, Pennsylvania State Coll. (Unpublished).

williams, R. D. 1931. Fertility of various herbage legumes. Welsh Pl. Breed. Stn

Bull. Ser.H. 12, 221-227.

williams, R. D. 1937a. Heterosis in red clover. Welsh 7. Agric., 13, 172-190.

WILLIAMS, R. D. $1937 b$. Genetics of red clover and its bearing on practical breeding.

Rep. 4th Int. Grassld Congr., 1937, 238-250.

williams, WATKIN. 1951. Genetics of incompatibility in Alsike clover, Trifolium hybridum. Heredity, 5, 51-73.

WRIGHT, D. S. G. 1964. Self and cross fertility in strawberry clover (Trifolium fragierum L.). N.Z. F. agric. Res., 7, 32-36.

\section{DATA: ADDENDUM TO TABLE 1}

\begin{tabular}{|c|c|c|c|c|c|c|}
\hline Sources & $\begin{array}{c}\text { Self-sterile } \\
\text { plants }\end{array}$ & $\begin{array}{c}\text { Self-fertile } \\
\text { plants }\end{array}$ & $\mid \begin{array}{c}\text { Total } \\
\text { plants }\end{array}$ & Florets & Seeds & $\begin{array}{c}\text { Mean } \\
\text { percentage } \\
\text { set }\end{array}$ \\
\hline $\begin{array}{l}\text { Mainly self-sterile (contd.) } \\
\text { 10. Wales (Cardiganshire) } \\
\text { 11. E. Germany (nr. Leipzig) } \\
\text { 12. Hungary }\end{array}$ & $\begin{array}{l}7 \\
8 \\
7\end{array}$ & $\begin{array}{l}0 \\
0 \\
0\end{array}$ & $\begin{array}{l}7 \\
8 \\
7\end{array}$ & $\begin{array}{r}440 \\
1062 \\
590\end{array}$ & $\begin{array}{l}0 \\
0 \\
7\end{array}$ & $\begin{array}{l}0 \\
0 \\
1 \cdot 2\end{array}$ \\
\hline $\begin{array}{l}\text { Mainly self-fertile (contd.) } \\
\text { 13. Sweden (Landskrona) } \\
\text { 14. U.S.S.R. (Uzbekistan) }\end{array}$ & $\begin{array}{l}3 \\
8\end{array}$ & $\begin{array}{l}4 \\
9\end{array}$ & $\begin{array}{r}7 \\
17\end{array}$ & $\begin{array}{l}1029 \\
206 \mathrm{I}\end{array}$ & $\begin{array}{l}417 \\
786\end{array}$ & $\begin{array}{l}40 \cdot 5 \\
38 \cdot 2\end{array}$ \\
\hline
\end{tabular}

